\title{
Rehabilitation time has greater influences on soil mechanical composition and erodibility than does rehabilitation land type in the hilly-gully region of the Loess Plateau, China
}

\author{
Leilei Qiao ${ }^{1}$, Wenjing Chen ${ }^{1,2}$, Yang Wu ${ }^{2}$, Hongfei Liu ${ }^{2}$, Jiaoyang Zhang ${ }^{3,4}$, Guobin Liu ${ }^{1,3}$, Sha Xue ${ }^{\text {Corresp. } 1,3}$ \\ ${ }^{1}$ State Key Laboratory of Soil Erosion and Dryland Farming on the Loess Plateau, Institute of Soil and Water Conservation, Northwest A\&F University, \\ Yangling, China \\ 2 Collage of Forestry, Northwest A\&F University, Yangling, China \\ 3 Institute of Soil and Water Conservation, Chinese Academy of Sciences and Ministry of Water Resources, Yangling, China \\ 4 University of Chinese Academy of Sciences, Beijing, China \\ Corresponding Author: Sha Xue \\ Email address: xuesha100@163.com
}

Background. The major landscape in the hilly-gully region of the Loess Plateau is greatly affected by vegetation rehabilitation on abandoned cropland. Although many studies have shown that the rehabilitation have greatly improved soil conditions and protected them from erosion, these effectiveness were not always in consensus possibly due to the land type of vegetation or to the rehabilitation time. To close this gap, we conducted a long term experiment as follows.

Methods. In this study, we analysed four land types of vegetation rehabilitation (shrub land, woodland, naturally revegetated grassland, and orchard land) with different rehabilitation times and investigated the mechanical composition and erodibility of the soil. Areas of slope croplandand natural forest were selected as controls.

Results. The results showed that soil depth, rehabilitation time and rehabilitation land type had strong impacts on soil mechanical composition, micro-aggregation and erodibility. Following rehabilitation, naturally revegetated grassland and shrub land had lower fractal dimensions of particle size distribution (fractal dimensions of PSD), fractal dimensions of micro-aggregation, and erodibility (K factor) than did cropland. Compared to the positive effects of rehabilitation mainly happened in the topsoil layer at other rehabilitation land type, that of woodland happened in the deeper soil layer. Besides, the indispensable rehabilitation time for the significant improvement of soil condition was shorter at naturally revegetated grassland than that at shrub land and woodland.

Discussion. Although rehabilitation time was more influential than was rehabilitation land type or soil depth, the differences among the rehabilitation land types showed that naturally revegetated grassland with native plants is the most time-saving rehabilitation vegetation for the Loess Plateau in the conversion from slope cropland. The success of rehabilitation in this forestry practice was mainly contributed by the suited species of rehabilitation land type to the local climate and soil. Based on the differences of rehabilitation effectiveness resulting from land type, we should be cautious to choose land types for the rehabilitation of soil conditions in the Loess Plateau. 
1 Rehabilitation time has greater influences on soil mechanical

2 composition and erodibility than does rehabilitation land type in

3 the hilly-gully region of the Loess Plateau, China

4

5 Leilei Qiao ${ }^{1} \boldsymbol{\Delta}$, Wenjing Chen ${ }^{1,2}$, Yang $\mathrm{Wu}^{2}$, Hongfei Liu ${ }^{2}$, Jiaoyang Zhang ${ }^{3,4}$,

6 Guobin $\mathrm{Liu}^{1,3}$, Sha Xue $\mathrm{X}^{1,3 *}$

7

$8{ }^{1}$ State Key Laboratory of Soil Erosion and Dryland Farming on the Loess Plateau, Institute of

9 Soil and Water Conservation, Northwest A\&F University, Yangling 712100, P. R. China.

$10 \quad{ }^{2}$ Collage of Forestry, Northwest A\&F University, Yangling 712100, P. R. China.

$11{ }^{3}$ Institute of Soil and Water Conservation, Chinese Academy of Sciences and Ministry of Water

12 Resources, Yangling 712100, P. R. China.

$13{ }^{4}$ University of Chinese Academy of Sciences, Beijing, China.

15 Address correspond Institute of Soil and Water Conservation, Northwest A\&F University,

Yangling 712100, P. R. China. E-mail: xuesha100@163.com

17

18

19

$\Delta$ Joint first authors

20

21 
Background. The major landscape in the hilly-gully region of the Loess Plateau is greatly that the rehabilitation have greatly improved soil conditions and protected them from erosion, these effectiveness were not always in consensus possibly due to the land type of vegetation or to the rehabilitation time. To close this gap, we conducted a long term experiment as follows.

Methods. In this study, we analysed four land types of vegetation rehabilitation (shrub land, woodland, naturally revegetated grassland, and orchard land) with different rehabilitation times and investigated the mechanical composition and erodibility of the soil. Areas of slope cropland and natural forest were selected as controls.

Results. The results showed that soil depth, rehabilitation time and rehabilitation land type had strong impacts on soil mechanical composition, micro-aggregation and erodibility. Following rehabilitation, naturally revegetated grassland and shrub land had lower fractal dimensions of particle size distribution (fractal dimensions of PSD), fractal dimensions of micro-aggregation, and erodibility ( $\mathrm{K}$ factor) than did cropland. Compared to the positive effects of rehabilitation mainly happened in the topsoil layer at other rehabilitation land type, that of woodland happened in the deeper soil layer. Besides, the indispensable rehabilitation time for the significant 
44 improvement of soil condition was shorter at naturally revegetated grassland than that at shrub 45 land and woodland.

46 Discussion. Although rehabilitation time was more influential than was rehabilitation land type

47 or soil depth, the differences among the rehabilitation land types showed that naturally

48 revegetated grassland with native plants is the most time-saving rehabilitation vegetation for the

49 Loess Plateau in the conversion from slope cropland. The success of rehabilitation in this

50 forestry practice was mainly contributed by the suited species of rehabilitation land type to the

51 local climate and soil. Based on the differences of rehabilitation effectiveness resulting from land

52 type, we should be cautious to choose land types for the rehabilitation of soil conditions in the

53 Loess Plateau.

54 Key word: erosion; vegetation rehabilitation; fractal dimension; Loess Plateau

\section{Introduction}

Soil erosion initiated by either natural or human factors is a serious environmental problem

57 in many parts of the world. It not only caused the degradation of soil quality but also the

58 destruction of ecosystem function and safety (Chen \& Peng 2000; Lian et al., 2013; Borrelli et

59 al. 2017). Severe soil erosion is a serious challenge in the Loess Plateau of China (Sun et al.,

60 2016b). To alleviate soil erosion and restore the local ecological environment, the Chinese

61 government implemented the "Grain for Green" programme in 1999 to convert degraded

62 cropland to forest and grassland (Uchida et al. 2005; Chen et al., 2007a; Uchida et al. 2009;

63 Zhang et al., 2011a; Song et al., 2015). This programme has greatly decreased soil loss (Chen et 
64

65

66

67

68

69

70

71

72

73

74

75

76

77

78

79

80

81

82

83

al., 2007b).

Several studies had examined the effects of plant species changes, land preparation, rainfall intensity, anthropogenic disturbance, afforestation, and land abandonment on the mechanical composition and erodibility of the soil (Koulouri \& Giourga 2007; Keesstra et al., 2009; Xia et al., 2009; Zhang et al., 2011b; Moora et al. 2014; Yu et al., 2017). Soil mechanical composition and micro-aggregate stability were shaped by complicated geophysical and environmental processes and responded to land-use changes, thereby affecting soil hydrological and mechanical functioning and soil erosion (Wang et al., 2005; Alagöz \& Yilmaz 2009; Xiao et al., 2014; Wang et al., 2016). Many studies have reported positive impacts of vegetation rehabilitation of sloped croplandon soil conditions and soil resistance to erosion (Xu et al., 2013; Ziadat \& Taimeh 2013; Xiao et al., 2014; Fu et al., 2015; Sun et al., 2016b). Different plant species, with differences in morphology, architecture and other biological characteristics, show variation in their effectiveness for vegetation rehabilitation (Bochet \& García-Fayos 2004; Ghestem et al. 2014; Fu et al., 2015). However, local precipitation, parent material, disturbance and their interaction and sampling time can influence vegetation rehabilitation and make interpretation of results challenging. Thus, long-term research on the dynamics of soil erosion is necessary to understand the effects of vegetation rehabilitation on soil physical condition while accounting for confounding factors. However, several studies have focused on the effects of different rehabilitation patterns or the dynamic changes following rehabilitation in a certain land type but have not clearly identified the impacts of the various rehabilitation land type on the soil 
84 mechanical composition and erodibility during a long-time scale. Soil erosion, solution transformation and soil-moisture are influenced by soil particle size distribution (PSD) (Mazaheri \& Mahmoodabadi 2012; Yu et al., 2015). Land use could influence soil structure and physical and biochemical activity through PSD affected by water erosion (Basic et al., 2004; Su et al., 2004). Therefore, its variation remains to be characterized for understanding and evaluating soil structure and dynamics and the effects of land use on soil structure. Fractal theory, an effective and reliable tool, can be used to characterize it (Chen and Zhou, 2013).

native grasslands into farmlands in the most parts of Loess Plateau of China, which caused the loss of most of the topsoil in many locations (Wei et al. 2006; Zhou et al. 2006). The "Grain for Green" Programs (GGP) launched by Chinese government aimed at reducing soil erosion through replacing degraded cropland with forest and grassland. Since then, a sloped cropland was abandoned and restored naturally and artificially. As we know, herbs, rather than trees or shrubs, were dominant on the Loess Plateau due to its special geological characteristics in a long historical period. A proper choice of rehabilitation land type for the success of afforestation is the key thing (Lu et al., 2003; Jiang et al., 2013). Thus, the difference of this rehabilitation effectiveness between native vegetation (naturally revegetated native grass) and common forestry afforestation (artificial ecological forest, artificial economic forest, artificial shrub) deserves our attention. In this study, we collected comprehensive and long-term data on historic vegetation (e.g., forest, shrubland and grassland) with different rehabilitation times (1) to 
104 elucidate the effects of rehabilitation land type, time and soil depth on soil mechanical condition

105 and erodibility; (2) to clearly identify the key influencing factors.

\section{Materials and methods}

107

108

109

110

111

112

113

114

115

116

117

118

\section{Experimental area}

This study was conducted in Ansai County, Shannxi Province, China $\left(36^{\circ} 31^{\prime}-37^{\circ} 20^{\prime} \mathrm{N}\right.$, $108^{\circ} 52^{\prime}-109^{\circ} 26^{\prime} \mathrm{E} ; 1,012-1,731 \mathrm{~m}$ a.s.1.), which lies in the middle part of the Loess Plateau. This region has a typical semiarid continental climate with a mean annual temperature of $8.8^{\circ} \mathrm{C}$, meaning that monthly temperature ranges from $22.5^{\circ} \mathrm{C}$ in July to $7^{\circ} \mathrm{C}$ in January and an annual precipitation of $549.1 \mathrm{~mm}$, which mainly occurs between July and September (Sun et al., 2016a). The landform is characterized by a deeply incised hilly-gully Loess landscape. The soil in this area is mainly Huangmian soil, a Calcic Cambisol classified in the WRB reference system (FAO/UNESCO/ISRIC, 1988), originating from wind-blown deposits and characterised by yellow color, absence of bedding, silty texture, looseness, macroporosity, and wetness-induced collapsibility (Xiao et al., 2014). This type of soil is characterized by weak cohesion (Sun et al., 2016a), which makes it highly susceptible to severe soil erosion.

cover of the Loess Plateau has been changing greatly during the historical period. The research about paleo-pedology, phytolith, organic carbon stable isotope and pollen records showed that herbs, rather than trees or shrubs, were dominant on the Loess Plateau in both the cold-dry period and the warm-humid period, owing to specific lithological property with thick loess which can 
124 not support an extensive forest development, even during the climatic optimum in this area (Lu 125 et al., 2003; Jiang et al., 2013). Overgrazing, deforestation and other land-use patterns led to 126 severe damage to the ecological environment and severe soil erosion by the middle of the last 127 century. Since the late 1950s, the land use type in this region changed remarkably by the GGP, 128 sloping cropland has been replanted with woodland (Robinia pseudoacacia), shrubland 129 (Caragana korshinskii, Hippophae rhamnoides), artificial grassland (Medicago sativa) and naturally revegetated grassland to control soil erosion (Sun et al., 2016b). Much of barren lands and degraded croplands with slopes over $15^{\circ}$ were rebuilt, accounting for about $14 \%$ of hilly Loess Plateau (Xu et al., 2018). Artificially and naturally rebuilt grassland, shrub land, and planted woodland consist of the main land use types in the region. includes woody plants such as Robinia pseudoacacia, shrubs as Hippophae rhamnoides and

\section{Sampling and data collection}


144 rehabilitation of cropland abandoned between July 10 and September 10 in 2011 and 2012, the

145 season in which plant community biomass peaks. The four types were naturally revegetated 146 grassland (with rehabilitation times of 2yr, 5yr, 8yr, 11yr, 15yr, 18yr, 26yr and 30yr), planted

147 shrubland (with rehabilitation times of 5yr, 10yr, 20yr, 30yr, 36yr, 47yr), planted woodland (with 148 rehabilitation times of 5yr, $10 \mathrm{yr}, 20 \mathrm{yr}, 37 \mathrm{yr}$ and 56yr), and orchard land (with rehabilitation 149 times of 5yr, $10 \mathrm{yr}$ and 20yr). All these sites suffering similar farming practices before 150 conversion, and the farmlands had more than 200 years of cultivation history (Deng et al., 2016).

151 Thus, sloping cropland sites were selected as representative of the original condition for the 152 rehabilitation chronosequences of the naturally revegetated grassland, revegetated shrub land, woodland and orchard land. In this area, the climax vegetation is the Quercus liaotungensis

Koidz (Zhang et al., 2011b), which were naturally regenerated on abandoned land from grassland to shrub land and climax forest (Q. liaotungensis) over about 150 years, based on previous research of secondary forests in this area. So, we considered it as representative of the soildominated climax community in vegetation rehabilitation to assess the effectiveness of vegetation rehabilitation. These selected sites offered representativeness, typicality and consistency and had similar slope gradients, slope aspects, and topography. The properties of the experimental sites are shown in Table 1. 
164 land site (Caragana microphylla, Hippophae rhamnoides) and in each orchard land site. The

165 smaller replicate plots $(2 \times 2 \mathrm{~m})$ were randomly established in each naturally revegetated

166 grassland site (including Artemisia sacrorum, A. capillaries, A. giraldii, Aneurolepidium

167 dasystachys, Bothriochloa ischaemum, Heteropappus altaicus, Lespedeza bicolor, Stipa

168 bungeana, Setaria viridis, and other grasses). The plots were separated by at least 50m.

169 We choose four random sampling to avoid the sampling error. At each sampling plot, after

170 removing ground litter, five soil layers $(0-10,10-20,20-30,30-50$, and 50-100cm) were

171 separately collected with a soil drilling sampler (4cm diameter). The soil samples from the same

172 layer of the same plot were mixed to form one sample. The samples were divided into two parts

173 and were passed through $2 \mathrm{~mm}$ screens for removing roots, gravel, and coarse fragments. Then

174 each sample was brought to laboratory. One part was naturally air-dried to measure the organic

175 carbon and analyse soil organic carbon (SOC), total nitrogen (TN), and total phosphorus (TP)

176 contents, particle size distributions and micro-aggregates. The other part was stored in a

177 refrigerator at $4^{\circ} \mathrm{C}$ to analyse water-soluble amounts (carbon, nitrogen), microbial biomass

178 (carbon, nitrogen), enzyme activity as well as other variables not reported in this paper.

\section{Physical and chemical analyses}

The soil bulk density (BD) of each soil layer was measured with the cutting ring method

181 (Ding et al., 2019). SOC was determined using the dichromate oxidation method (Nelson \&

Sommers, 1982), and TN was determined using the Kjeldahl method (Bremner, 1982). For soil 
184 laser diffraction technique using a Longbench Mastersizer 2000 (Malvern Instruments, Malvern, 185 England) (Xiao et al., 2014). There are some differences between the pretreatment methods for 186 determining soil PSD and micro-aggregate. For soil PSD, soil samples were pretreated with 6\% $187 \mathrm{H}_{2} \mathrm{O}_{2}$ and $10 \% \mathrm{HCL}$ to remove organic matter and carbonates and oxides and were soaked in 188 distilled water for $24 \mathrm{~h}$, then mechanically dispersed with $0.4 \%$ Calgon by an ultrasonic bath for $1895 \mathrm{~min}$. For micro-aggregate determination, the soil samples were soaked in distilled water for 24 $190 \mathrm{~h}$ and mechanically dispersed in ultrasonication for $5 \mathrm{~min}$ (Xiao et al., 2014). Soil PSD was 191 described in terms of the percentage of sand $(0.05-2 \mathrm{~mm})$, fine silt $(0.002-0.020 \mathrm{~mm})$, coarse 192 silt $(0.02-0.05 \mathrm{~mm})$ and clay $(<0.002 \mathrm{~mm})$. The size grades of the micro-aggregates were 193 classified to be the same as that of the PSD.

194

195 196

\section{Fractal features}

The fractal dimension of the PSD and micro-aggregation were calculated by the following formula (Tyler \& Wheatcraft 1992):

$$
V\left(r<R_{i}\right) / V_{T}=\left(R_{i} / R_{\max }\right)^{3-D}
$$

where $r$ is the particle diameter, $R_{i}$ is the particle size of subinterval $i$ in the particle size grading, $\mathrm{V}\left(r<R_{i}\right)$ is the total volume of soil particles with diameter less than $R_{i}, V_{T}$ is the sum volume of soil particles, and Rmax is the maximum diameter of soil particles.

\section{Erodibility (K)}

Soil erodibility was measured by the $\mathrm{K}$ factor in the EPIC model using SOC content and 
203

204

205

206

207

208

209

210

211

212

213

214

215

216

217

218

219

220

221

soil PSD (Williams et al., 1984) and was calculated as follows:

$$
\begin{gathered}
\mathrm{K}=\{0.2+0.3 \exp [-0.0256 \mathrm{SAN}(1-0.01 \mathrm{SIL})]\} \times\left(\frac{\mathrm{SIL}}{\mathrm{CLA}+\mathrm{SIL}}\right)^{0.3} \times\left(1.0-\frac{0.25 \mathrm{C}}{\mathrm{C}+\exp ?(3.72-2.95 \mathrm{C})}\right) \times \\
\left(1.0-\frac{0.25 \mathrm{C}}{\mathrm{SN} 1+\exp ?(-5.51+22.9 \mathrm{SN} 1)}\right)
\end{gathered}
$$

where SAN, SIL, and CLA are the sand (\%), silt (\%), and clay (\%) fractions, respectively;

$\mathrm{C}$ is the soil organic carbon content (\%); and $\mathrm{SNI}=1-\mathrm{SAN} / 100$.

\section{Statistical analysis}

Three-way ANOVA was performed to test the effects of rehabilitation land type (naturally revegetated grassland, woodland, shrub land, orchard land), rehabilitation time (years since sloping cropland abandonment) and soil depth $(0-10 \mathrm{~cm}, 10-20 \mathrm{~cm}, 20-30 \mathrm{~cm}, 30-50 \mathrm{~cm}$, and $50-$ $100 \mathrm{~cm}$ ) on soil mechanical composition and erodibility. Significance was evaluated at the 0.05 level $(\mathrm{P}<0.05)$. Duncan's $(\mathrm{D})$ post hoc test was used to perform multiple comparisons when significance of the ANOVA was observed. The differences between the natural forest and various types of vegetation rehabilitation at each last restoration year were examined by student's t test. Pearson correlation analysis was used to analyse the correlations among particle fractal dimension, micro-aggregate fractal dimension, erodibility and soil nutrients, soil texture, and recovery time. In addition, linear regression analysis was used to determine the relationships between each of particle fractal dimension, micro-aggregate fractal dimension, and erodibility and recovery time in each soil layer between 0 and $100 \mathrm{~cm}$. All of the above statistical analyses were conducted using SPSS 17.0 (SPSS Inc., Chicago, IL, USA) and R version 3.4.4. 
222

223

224

225

226

227

228

229

230

231

232

233

234

235

236

237

238

239

240

\section{Results}

Rehabilitation time, and rehabilitation land type had significant effects on the soil PSD

fractal dimension and $\mathrm{K}$ factor, only the rehabilitation land type had significant effects on the soil micro-aggregate fractal dimension (Table 2). PSD fractal dimension, micro-aggregate fractal dimension and erodibility showed trends of decline since cropland in all land types. However, PSD fractal dimension, micro-aggregate fractal dimension and erodibility varied among the land types (Figure 2-4).

\section{The rehabilitation pattern in naturally revegetated grassland}

Fractal dimensions of PSD and $\mathrm{K}$ factor began to show greater decreases in naturally revegetated grassland than in cropland at $5^{\text {th }}, 11^{\text {th }}$ years, respectively, since cropland abandonment. And these trends mainly occurred in $0-20 \mathrm{~cm}$, gradually weaken with depth. Overall, the minimum time before significant decreases appeared in the particle fractal dimension, soil micro-aggregate fractal dimension and erodibility varied among the different rehabilitation land types; in general, the times were shorter for naturally revegetated grassland than for the other land types (Figure 2-4) (Table 1-3). Naturally revegetated grassland did not differ from natural forest in fractal dimensions of micro-aggregation or K factor $(20-100 \mathrm{~cm})$ over rehabilitation time (Figure 5-7) (Table 1-3). Linear regression revealed that fractal dimensions of PSD decreased with the number of years since farmland conversion in the $0-50 \mathrm{~cm}$ (except in 20 30cm)(Figure 2-4) (Table 1-3). 
241

242

243

244

245

246

247

248

249

250

251

252

253

254

255

256

257

258

259

260

\section{The rehabilitation pattern in Wood land}

Fractal dimensions of PSD, fractal dimensions of micro-aggregation and $\mathrm{K}$ factor began to show greater decrease in woodland than in cropland in the $10^{\text {th }}, 10^{\text {th }}$ and $37^{\text {th }}$ respectively since cropland abandonment (Figure 2-4) (Table 1-3). Over rehabilitation time, woodland did not differ from natural forest in fractal dimensions of PSD $(30-100 \mathrm{~cm})$ and fractal dimensions of micro-aggregation $(0-100 \mathrm{~cm}), \mathrm{K}$ factor in woodland did not differ from natural forest $(0$ $30 \mathrm{~cm})$ and even was lower than that in natural forest $(30-100 \mathrm{~cm})$ (Figure 5-7) (Table 1-3). Compared to fractal dimensions of micro-aggregation and $\mathrm{K}$ factor, fractal dimensions of PSD in this site showed a clear decreasing tend at the all soil layers (Figure 2-4) (Table 1-3).

\section{The rehabilitation pattern in Shrub land}

Fractal dimensions of PSD, fractal dimensions of micro-aggregation and $\mathrm{K}$ factor began to show greater decreases in shrub land than in cropland in the $20^{\text {th }}, 36^{\text {th }}$ and $30^{\text {th }}$ years, respectively, since cropland abandonment, and tended to have significant differences with cropland since then (Figure 2-4) (Table 1-3). The decreasing trend of fractal dimensions of PSD and fractal dimensions of micro-aggregation occurred in $0-100 \mathrm{~cm}$, but it gradually weaken with increasing depth. After rehabilitation, naturally revegetated grassland were also higher than natural forest in fractal dimensions of PSD $(0-50 \mathrm{~cm})$, fractal dimensions of micro-aggregation $(0-30 \mathrm{~cm})$ and $\mathrm{K}$ factor $(0-10 \mathrm{~cm})$ (Figure 5-7) (Table 1-3), and had no difference with that of natural forest at the deep layer. Linear regression indicated that fractal dimensions of PSD decreased with the number of years since farmland conversion in the $0-100 \mathrm{~cm}$ (except $30-50 \mathrm{~cm})$ 
261 (Figure 2-4) (Table 1-3).

262

263

264

265

266

267

268

269

270

\section{The rehabilitation pattern in Orchard land}

Fractal dimensions of PSD and fractal dimensions of micro-aggregation showed a trend of

lower levels in orchard land than in cropland, but there are no significant differences between

them (Figure 2-4) (Table 1-3). However, K factor in this site didn't decrease after a long-term rehabilitation. Following rehabilitation, fractal dimensions of PSD, fractal dimensions of micro-

aggregation, and $\mathrm{K}$ factor were significantly higher in orchard land than in natural forest at

shallow soil layer (Figure 5-7) (Table 1-3). Linear regression revealed that fractal dimensions of

PSD decreased with the number of years since farmland conversion in the $0-10 \mathrm{~cm}$ soil layers

(Figure 2-4) (Table 1-3). 


\section{Discussion}

\section{Effects of rehabilitation time on soil mechanical composition and erodibility}

In our study, rehabilitation time was a key factor in driving changes in soil mechanical

274

275

276

277 condition, erodibility and properties (Table 2) (Figure 8). The fractal dimensions of PSD, K factor of the soil in the various rehabilitation land types showed decreasing trends following rehabilitation (Figure 2-4) (Table 1-3). These changes were mainly due to the large amounts of soil nutrients released by residues and decomposing dead roots, and they promote plant growth and rehabilitation succession (Guo et al., 2013). Fractal dimensions of PSD, K factor positively correlated with SOC, and the improvement of mechanical conditions were mainly explained by the soil nutrient levels (Table 3). Soil organic matter, as a binding agent, favoured soil structure stabilization and infiltration and protected it from erosion (García-Orenes et al. 2012). In addition, well-developed root systems played a vital role in soil mechanical functioning and actively exude substrates, such as polysaccharides, phenolic compounds, and polygalacturonic acid that affect soil particle cohesion and aggregation (Hodge et al. 2009; Sun et al., 2016b). Furthermore, by directly binding soil particles in situ, plant roots prevented soil from being blown or washed away (Reubens et al., 2007). Dense canopies and ground litter following rehabilitation protected soil aggregates from breakdown and prevent particles from being washed away by raindrop energy and runoff (Zuazo \& Pleguezuelo 2009; Wang et al., 2008). 
289

290

291

292

293

294

295

296

297

298

299

300

301

302

303

304

305

306

307

308

\section{Effects of rehabilitation land type on soil mechanical composition and erodibility}

Vegetation rehabilitation type was the most influential factor in driving soil mechanical

composition and erodibility (Table 2) (Figure 8). Variation in vegetation recovery patterns and

plant traits led to variation in the production and release of soil organic matter, which affect soil

crusting, splash, aggregate size and stability. For example, high levels of soil organic matter

reduced soil vulnerability to detachment by surface flow, rain splash and other erosion-inducing

phenomena (Xiao et al., 2014; Fu et al., 2015). Litters with different chemical composition

among different plant species would impact decomposition rates and the release of soil organic

matter (Ayres et al., 2006). Thus, naturally revegetated grassland site dominated with high

quality litter showed faster circulating rates than shrub and tree sites dominated with relative low

quality litter. This phenomenon may explain why the recovery time needed to reach significant

improvements of soil mechanical conditions and soil erosion was shorter for naturally

revegetated grassland than for woodland and shrub land. Our results are in accordance with the

study of Yu et al. (2015), which showed that high concentrations of soil organic matter greatly

affected the fractal dimensions of PSD and generally facilitated the improvement of soil

structure. The species of naturally revegetated grassland on the whole corresponds with the

native vegetation specieson on Loess Plateau during a long historical period (Lu et al., 2003;

Jiang et al., 2013). They belong to Poaceae and Asteraceae families which are tolerant to

drought, cold and grazing due to the characteristics of low water requirements, fibrous root

system, are fully suited to the local arid or semi-arid climates and soil (Lu et al., 2003; Jiang et

Peer] reviewing PDF | (2019:05:37265:3:0:NEW 18 Oct 2019) 
309

310

311

312

313

314

315

316

317

318

319

320

321

322

323

324

325

326

327

al., 2013). Thick loess was mainly caused by the loosely cemented silt (Liu 1985; Yang \& Ding 2008) which allows rainwater to infiltrate quickly (Yang et al. 2012). Thus, naturally revegetated grass as native Loess Plateau vegetation were the best selected species for rehabilitation of soil conditions. Cespedes et al., (2012) even found that afforestation with fast growing exotic species showing its negative effects on soil, compared to native grassland.

In addition, vegetation alleviates erosion of soil by its canopy effectively reducing waterinduced soil erosion (Mohammad \& Adam 2010; Wei et al., 2010). However, that effectiveness was different from various land types. In naturally revegetated grassland site, the lower vegetation layer was more effective in reducing the kinetic energy of rainfall striking the soil surface than the tall vegetation in shrub land and woodland. Owing to the lack of roots at deep soil layer, the naturally revegetated grassland only showed positive effect at the shallow soil layer $(0-10 \mathrm{~cm})$. However, due to the stronger stretching ability of the trees roots, woodland site also showed the potential of alleviate soil erosion at deep layer. The soil loss in orchard land was continued over a long time owing to human disturbances (such as production management and tillage practices) and the absence of surface cover protection. This leads to the breakdown of shallow soil aggregates and the washing away of soil particles by raindrop energy and runoff (Wang et al., 2008).

\section{Effects of soil depth on soil fractal dimension and erodibility}

In the analysed four types of vegetation rehabilitation, soil depth had large influences on 
328 soil mechanical composition and erodibility (Table 2) (Figure. 8) being consistent with previous

329 studies (Xiao et al., 2014). In our study, the positive effects of vegetation recovery mainly

330 occurred in the topsoil with the higher reduction rates of fractal dimensions of PSD, fractal

331 dimensions of micro-aggregation and $\mathrm{K}$ factor in the topsoil than in the subsoil (Figures 2-4)

332 (Table 1-3). This pattern was resulting from the variation in plant root distribution density

333 decreasing along soil depth (Reubens et al., 2007); thus, the deeper soil layers were, the weaker

334 the improvements of soil conditions were (Sun et al., 2014). In addition, soil nutrients

335 accumulated near the soil surface due to the decomposition of vegetation litter and by influence

336 of the biogeochemical cycling (Wang et al., 2014).

\section{Conclusion}

338 Our study suggested that vegetation rehabilitation time, type and soil depth significantly

339 affect soil mechanical composition and erosion. Following the conversion of sloping cropland to naturally revegetated grassland, shrub land or woodland, the soil structure gradually recovered, and the resistance of the soil against erosive forces gradually increased, primarily within the topsoil. For the conversion of sloping cropland, the natural restoration process of grass represents geological conditions, such as the naturally revegetated grass in our study. Based on the 
348 study, conducted at the regional scale, revealed the effects of vegetation rehabilitation on soil

349 erosion in the Loess Plateau, China, but it strongly contributes to our understanding of the

350 mechanisms through which rehabilitation improves soil quality and provides a suggestion for

351 ecosystem management in arid and semi-arid regions.

\section{Acknowledgements}

353 We thank the anonymous referees and editors of the journal who provided valuable

354

355

356

357

358

359

360

361

362

363

364

comments and suggestions on our manuscript. This research was funded by the National Key

Research and Development Program of China (2016YFC0501707).

\section{References}

Alagöz Z, Yilmaz E. 2009. Effects of different sources of organic matter on soil aggregate formation and stability: A laboratory study on a Lithic Rhodoxeralf from Turkey. Soil and Tillage Research 103: 419-424.

Ayres E, Dromph KM, Bardgett RD. 2006. Do plant species encourage soil biota that specialise in the rapid decomposition of their litter? Soil Biology \& Biochemistry 38: 183186.

Basic F, Kisic I, Mesic M, Nestroy O, Butorac A. 2004. Tillage and crop management effects on soil erosion in central Croatia. Soil \& Tillage Research 78: 197-206.

Blanco-Canqui H, Lal R. 2008. Principles of soil conservation and management. Springer Science \& Business Media. 
367

368

Bochet E, García-Fayos P. 2004. Factors Controlling Vegetation Establishment and Water Erosion on Motorway Slopes in Valencia, Spain. Restoration Ecology 12: 166-174.

Borrelli P, Robinson DA, Fleischer LR, Lugato E, Ballabio C, Alewell C, Meusburger K, Modugno S, Schütt B, Ferro V, Bagarello V, Oost KV, Montanarella L, Panagos P. 2017. An assessment of the global impact of 21 st century land use change on soil erosion. Nature Communications 8:2013.

Bremner JM, Mulvaney CS. 1982. Nitrogen-total. Agronomy monography 9. In: Page A L, Miller R H, Keeney D R. Methods of Soil Analysis, Part 2, Chemical and Microbial Properties, Madison: Agronomy Society of America, 595-624.

Cespedes-Payret C, Piñeiro G, Gutierrez O, Panario D. 2012. Land use change in a temperate grassland soil: Afforestation effects on chemical properties and their ecological and mineralogical implications. Science of the Total Environment 438: 549-557.

Chen F, Peng BZ. 2000. The effect of land use changes on soil conditions in arid region. Chinese Geographical Science 10: 226-230.

Chen L, Fu GB, Huang Z, Huang Y, Gui L. 2007. Effect of land use conversion on soil organic carbon sequestration in the loess hilly area, loess plateau of China. Ecological Research 22: 641-648 DOI 10.1007/s11284-006-0065-1.

Chen L, Wei W, Fu B, Lu Y. 2007. Soil and Water Conservation on the Loess Plateau in China: Review and Perspective. Progress in Physical Geography 31: 389-403 DOI 10.1177/0309133307081290. 
387 Chen, X, Zhou, J. 2013. Volume-based soil particle fractal relation with soil erodibility in a small watershed of purple soil. Environmental Earth Sciences 70: 1735-1746.

389

390

391

392

393

394

395

396

397

398

399

400

401

402

403

404

405

Deng, L, Wang, K, Tang, Z, Shangguan Z. 2016. Soil organic carbon dynamics following natural vegetation restoration: Evidence from stable carbon isotopes ( $\delta 13 \mathrm{C})$. Agriculture Ecosystems \& Environment 221: 235-244.

Ding L, Wang P, Zhang W, Zhang Y, Li S, Wei X, Yang F. 2019. Shrub Encroachment Shapes Soil Nutrient Concentration, Stoichiometry and Carbon Storage in an Abandoned Subalpine Grassland. Sustainability 11: 1732.

Fu BJ, Wang YF, Lu YH, He CS, Chen LD, Song CJ.c 2015. The effects of land-use combinations on soil erosion: a case study in the Loess Plateau of China. Progress in Physical Geography 33: 793-804.

FAO/UNESCO/ISRIC. 1988. Soil map of the world; revised legend. World Soil ResourceReport, vol. 60. Rome, Food and Agriculture Organization of the United Nations.

\section{García-Orenes F, Roldán A, Mataix-Solera J, Cerdà A, Campoy M, Arcenegui V, Caravaca} F. 2012. Soil structural stability and erosion rates influenced by agricultural management practices in a semi-arid Mediterranean agro-ecosystem. Soil Use and Management 28: 571579.

Gao L, Bowker MA, Xu M, Sun H, Tuo D, Zhao Y. 2017. Biological soil crusts decrease erodibility by modifying inherent soil properties on the Loess Plateau, China. Soil Biology 
\& Biochemistry 105: 49-58.

407

408

409

410

411

412

Ghestem M, Veylon G, Bernard A, Vanel Q, Stokes A. 2014. Influence of plant root system morphology and architectural traits on soil shear resistance. Plant and Soil 377: 43-61.

\section{Guo C, Dannenmann M, Gasche R, Zeller B, Papen H, Polle A, Rennenberg H, Simon J.} 2013. Preferential use of root litter compared to leaf litter by beech seedlings and soil microorganisms. Plant \& Soil 368: 519-534.

Hodge A, Berta G, Doussan C, Merchan F, Crespi M. 2009. Plant root growth, architecture and function. Plant and Soil 321: 153-187.

Hu F, Liu J, Xu C, Wang Z, Liu G, Li H, Zhao S. 2018. Soil internal forces initiate aggregate breakdown and splash erosion. Geoderma 320: 43-51.

Hu J, Lu Y, Fu B, Comber AJ, Harris P. 2017. Quantifying the effect of ecological restoration on runoff and sediment yields: A meta-analysis for the Loess Plateau of China. Progress in Physical Geography-Earth 41: 753-774.

Jiang W, Cheng Y, Yang X, Yang S. 2013. Chinese Loess Plateau vegetation since the Last Glacial Maximum and its implications for vegetation restoration. Journal of Applied Ecology 50: 440-448.

Keesstra SD, Dam OV, Verstraeten G, Huissteden JV. 2009. Changing sediment dynamics due to natural reforestation in the Dragonja catchment, SW Slovenia. Catena 78(1): 60-71. 
424 Koulouri M, Giourga C. 2007. Land abandonment and slope gradient as key factors of soil erosion in Mediterranean terraced lands. Catena 69: 274-281.

426

427

Lian J, Zhao XY, Zuo XA, Wang SK, Wang XY, Luo YQ. 2013. Land cover changes and the effects of cultivation on soil properties in Shelihu wetland, Horqin Sandy Land, Northern China. Journal of Arid Land 5: 71-79.

Liu, GB. 1999. Soil conservation and sustainable agriculture on the Loess Plateau: Challenges and prospects. Ambio: 663-668.

Liu SL, Guo XD, Fu BJ, Lian G, Wang J. 2007. The effect of environmental variables on soil characteristics at different scales in the transition zone of the Loess Plateau in China. Soil Use and Management 23: 92-99.

Liu D S. 1985. Loess and the Environment. China Ocean Press, Beijing.

Chen H, Shao M, Li Y. 2008. Soil desiccation in the Loess Plateau of China. Geoderma 143: 91-100.

Lü H, Liu D, Guo Z. 2003. Natural vegetation of geological and historical periods in Loess Plateau. Chinese Science Bulletin 48: 411-416.

Mazaheri MR, Mahmoodabadi M. 2012. Study on infiltration rate based on primary particle size distribution data in arid and semiarid region soils. Arabian Journal of Geosciences 5: 1039-1046. 
442 Mohammad AG, Adam MA. 2010. The impact of vegetative cover type on runoff and soil erosion under different land uses. Catena 81: 97-103.

444

445

446

447

448

449

450

451

452

453

454

455

456

457

458

459

\section{Moora M, Davison J, Öpik M, Metsis M, Saks Ü, Jairus T, Vasar M, Zobel M. 2014.} Anthropogenic land use shapes the composition and phylogenetic structure of soil arbuscular mycorrhizal fungal communities. FEMS microbiology ecology 90: 609-621.

Nelson DW, Sommers LE. 1982. Total carbon, organic carbon, and organic matter. Agronomy nonograph 9. In: Page A L, Miller RH, Keeney DR. Methods of Soil Analysis, Part 2, Chemical and Microbial Properties. Madison: Agronomy Society of America, 539-552.

Parysow P, Wang G, Gertner G, Anderson AB. 2003. Spatial uncertainty analysis for mapping soil erodibility based on joint sequential simulation. Catena 53: 65-78.

Reubens B, Poesen J, Danjon F, Geudens G, Muys B. 2007. The role of fine and coarse roots in shallow slope stability and soil erosion control with a focus on root system architecture: a review. Trees 21: 385-402.

Song Z, Zhang C, Liu G, Dong Q, Xue S. 2015. Fractal Feature of Particle-Size Distribution in the Rhizospheres and Bulk Soils during Natural Recovery on the Loess Plateau, China. Plos One 10: e 0138057.

Su YZ, Zhao HL, Zhao WZ, Zhang TH. 2004. Fractal features of soil particle size distribution and the implication for indicating desertification. Geoderma 122: 43-49. 
460 Sun C, Liu G, Xue S. 2016. Land-Use Conversion Changes the Multifractal Features of

461 Particle-Size Distribution on the Loess Plateau of China. International Journal of

462 Environmental Research \& Public Health 13: 785.

463

464

465

466

467

468

469

470

471

472

473

474

475

476

477

Sun C, Liu G, Xue S. 2016. Natural succession of grassland on the Loess Plateau of China affects multifractal characteristics of soil particle-size distribution and soil nutrients. Ecological Research 31: 891-902.

Sun W, Shao Q, Liu J, Zhai J. 2014. Assessing the effects of land use and topography on soil erosion on the Loess Plateau in China. Catena 121: 151-163

Tyler SW, Wheatcraft SW. 1992. Fractal Scaling of Soil Particle-Size Distributions: Analysis and Limitations. Soil Science Society of America Journal 56: 362-369 .

Uchida E, Rozelle S, Xu J. 2009. Conservation payments, liquidity constraints, and off-farm labor: impact of the Grain-for-Green Program on rural households in China. American Journal of Agricultural Economics 91: 70-86.

Uchida E, Xu J, Rozelle S. 2005. Grain for Green: Cost-Effectiveness and Sustainability of China's Conservation Set-Aside Program. Land Economics 81: 247-264.

Wang B, Liu GB, Xue S, Zhu B. 2011. Changes in soil physico-chemical and microbiological properties during natural succession on abandoned farmland in the Loess Plateau. Environmental Earth Sciences 62: 915-925. 
478

479

480

481

482

483

484

485

486

487

488

489

490

491

492

493

494

495

Wang D, Fu B, Zhao W, Hu H, Wang Y. 2008. Multifractal characteristics of soil particle size distribution under different land-use types on the Loess Plateau, China. Catena 72: 29-36.

Wang G, Gertner G, Liu X, Anderson A. 2001. Uncertainty assessment of soil erodibility factor for revised universal soil loss equation. Catena 46: 1-14.

Wang HM, Wang WJ, Chen H, Zhang Z, Mao Z, Zu YG. 2014. Temporal changes of soil physic-chemical properties at different soil depths during larch afforestation by multivariate analysis of covariance. Ecology \& Evolution 4: 1039-1048.

Wang JG, Yang W, Yu B, Li ZX, Cai CF, Ma RM. 2016. Estimating the influence of related soil properties on macro- and micro-aggregate stability in ultisols of south-central China. Catena 137: 545-553.

Wang XD, Liu SZ, Liu GC. 2005. Fractal Characteristics of Soil under Different Land-Use Patterns in the Arid and Semi-Arid Region of the Western Tibet Plateau, China. Wuhan University Journal of Natural Sciences 10: 785-790.

Wei J, Zhou J, Tian JL, He XB, Tang KL. 2006 Decoupling soil erosion and human activities on the Chinese Loess Plateau in the 20th century. Catena 68:10-15.

Wei W, Chen L, Fu B, Chen J. 2010. Water erosion response to rainfall and land use in different drought-level years in a loess hilly area of China. Catena 81: 24-31.

Williams JR, Jones CA, Dyke PT, 1984. A modeling approach to determining the relationship 
497

498

499

500

501

502

503

504

505

506

507

508

509

510

511

512

513

514

Xia L, Zhang GC, Heathman GC, Wang YQ, Huang CH. 2009. Fractal features of soil particle-size distribution as affected by plant communities in the forested region of Mountain Yimeng, China. Geoderma 154: 123-130.

Xiao L, Xue S, Liu GB, Zhang C. 2014. Fractal features of soil profiles under different land use patterns on the Loess Plateau, China. Journal of Arid Land 6: 550-560.

Xu M, Wang Z, Zhao Y. 2018. Stratification ratio of soil organic carbon as an indicator of carbon sequestration and soil quality in ecological restoration. Restoration Ecology 26: 555562.

Xu G, Li Z, Li P. 2013. Fractal features of soil particle-size distribution and total soil nitrogen distribution in a typical watershed in the source area of the middle Dan River, China. Catena 101: 17-23.

Yang SL, Ding ZL, Wang X, Tang ZH, Gu ZY. 2012. Negative $\delta^{18} \mathrm{O}-\delta 13 \mathrm{C}$ relationship of pedogenic carbonate from northern China indicates a strong response of $\mathrm{C}_{3} / \mathrm{C}_{4}$ biomass to the seasonality of Asian monsoon precipitation. Palaeogeography, Palaeoclimatology, Palaeoecology 317-318: 32-40.

Yang SL, Ding ZL. 2008. Advance-retreat history of the East-Asian summer monsoon rainfall belt over Northern China during the last two glacial-interglacial cycles. Earth and Planetary Science Letters 274: 499-510. 
515 Yu J, Lv X, Bin M, Wu H, Du S, Zhou M, Yang Y, Han G. 2015. Fractal features of soil

516 particle size distribution in newly formed wetlands in the Yellow River Delta. Scientific

$517 \quad$ Reports 5: 10540.

518 Zhang C, Xue S, Liu GB, Song, ZL. 2011. A comparison of soil qualities of different

519 revegetation types in the Loess Plateau, China. Plant \& Soil 347: 163-178.

520

521

522

Zhang GH, Liu GB, Wang GL, Wang, YX. 2011. Effects of Vegetation Cover and Rainfall Intensity on Sediment-Bound Nutrient Loss, Size Composition and Volume Fractal Dimension of Sediment Particles. Pedosphere 21: 676-684.

Su ZA, Zhang JH, Nie XJ. 2010. Effect of Soil Erosion on Soil Properties and Crop Yields on Slopes in the Sichuan Basin, China. Pedosphere 20: 736-746.

Zheng FL. 2006. Effect of Vegetation Changes on Soil Erosion on the Loess Plateau. Pedosphere 16: 420-427.

Ziadat FM, Taimeh AY. 2013. Effect of rainfall intensity, slope, land use and antecedent soil moisture on soil erosion in an arid environment. Land Degradation \& Development 24: $582-590$.

Zhu B, Li Z, Li P, Liu G, Xue S. 2010. Soil erodibility, microbial biomass, and physicalchemical property changes during long-term natural vegetation rehabilitation: a case study in the Loess Plateau, China. Ecological Research 25: 531-541. 
533 Zhuang J, Mccarthy JF, Perfect E, Mayer LM, Jastrow JD. 2008. Soil Water Hysteresis in 534 Water-Stable Microaggregates as Affected by Organic Matter. Soil Science Society of $535 \quad$ America Journal 72: 212-220.

536 Zhang YW, Deng L, Yan WM, Shangguan ZP. 2016. Interaction of soil water storage 537 dynamics and long-term natural vegetation succession on the Loess Plateau, China. Catena $538 \quad$ 137: $52-60$.

Zuazo VHD, Pleguezuelo CRR. 2009. Soil-erosion and runoff prevention by plant covers: a $540 \quad$ review. Sustainable agriculture: Springer, 785-811.

Zhou ZC, Shangguan ZP, Zhao D. 2006. Modeling vegetation coverage and soil erosion in the Loess Plateau Area of China. Ecol Model 198:263-268. 
Figure 1

Fig. 1. Location of the Loess Plateau China

Fig. 1. Location of the Loess Plateau China

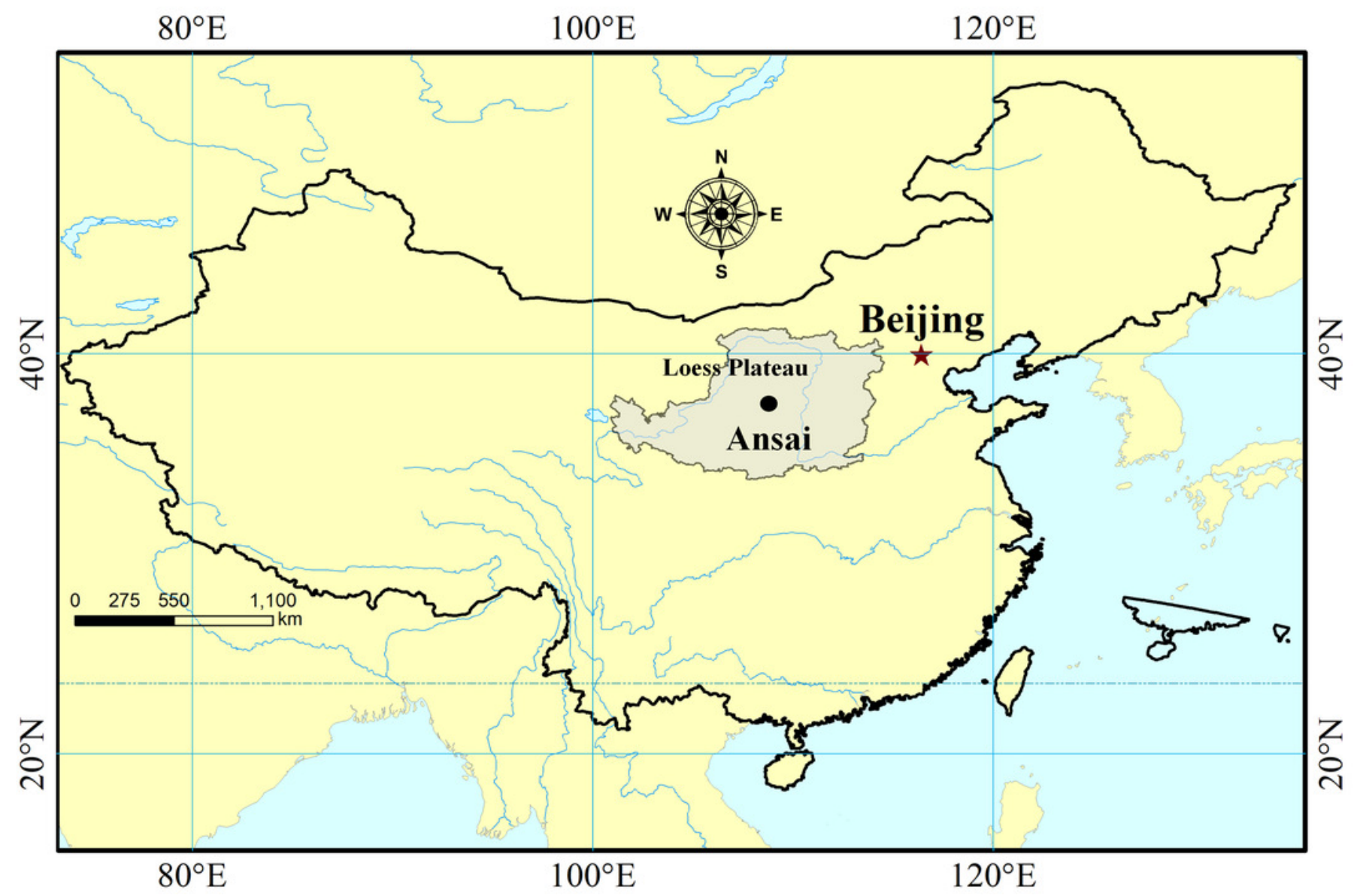




\section{Figure 2}

Fig. 2. Particle fractal dimension change with time since cropland abandonment in various vegetation restoration patterns.

Note: NG: naturally revegetated grassland, WL: woodland, SL: shrub land, OL: orchard land. We set the $C L$ as the initial stage of the rehabilitation process. (A-E): the soil layers of $0-10 \mathrm{~cm}, 10-20 \mathrm{~cm}, 20-30 \mathrm{~cm}, 30-50 \mathrm{~cm}$ and $50-100 \mathrm{~cm}$ of naturally revegetated grassland, $(F-$ $\mathrm{K})$ : the soil layers of $0-10 \mathrm{~cm}, 10-20 \mathrm{~cm}, 20-30 \mathrm{~cm}, 30-50 \mathrm{~cm}$ and $50-100 \mathrm{~cm}$ of woodland, (L-O): the soil layers of $0-10 \mathrm{~cm}, 10-20 \mathrm{~cm}, 20-30 \mathrm{~cm}, 30-50 \mathrm{~cm}$ and $50-100 \mathrm{~cm}$ of shrub land, (P-T): the soil layers of $0-10 \mathrm{~cm}, 10-20 \mathrm{~cm}, 20-30 \mathrm{~cm}, 30-50 \mathrm{~cm}$ and $50-100 \mathrm{~cm}$ of orchard land.

Different lower-case letters above the bars mean significant differences among different ages within the same rehabilitation patterns $(P<0.05)$. 

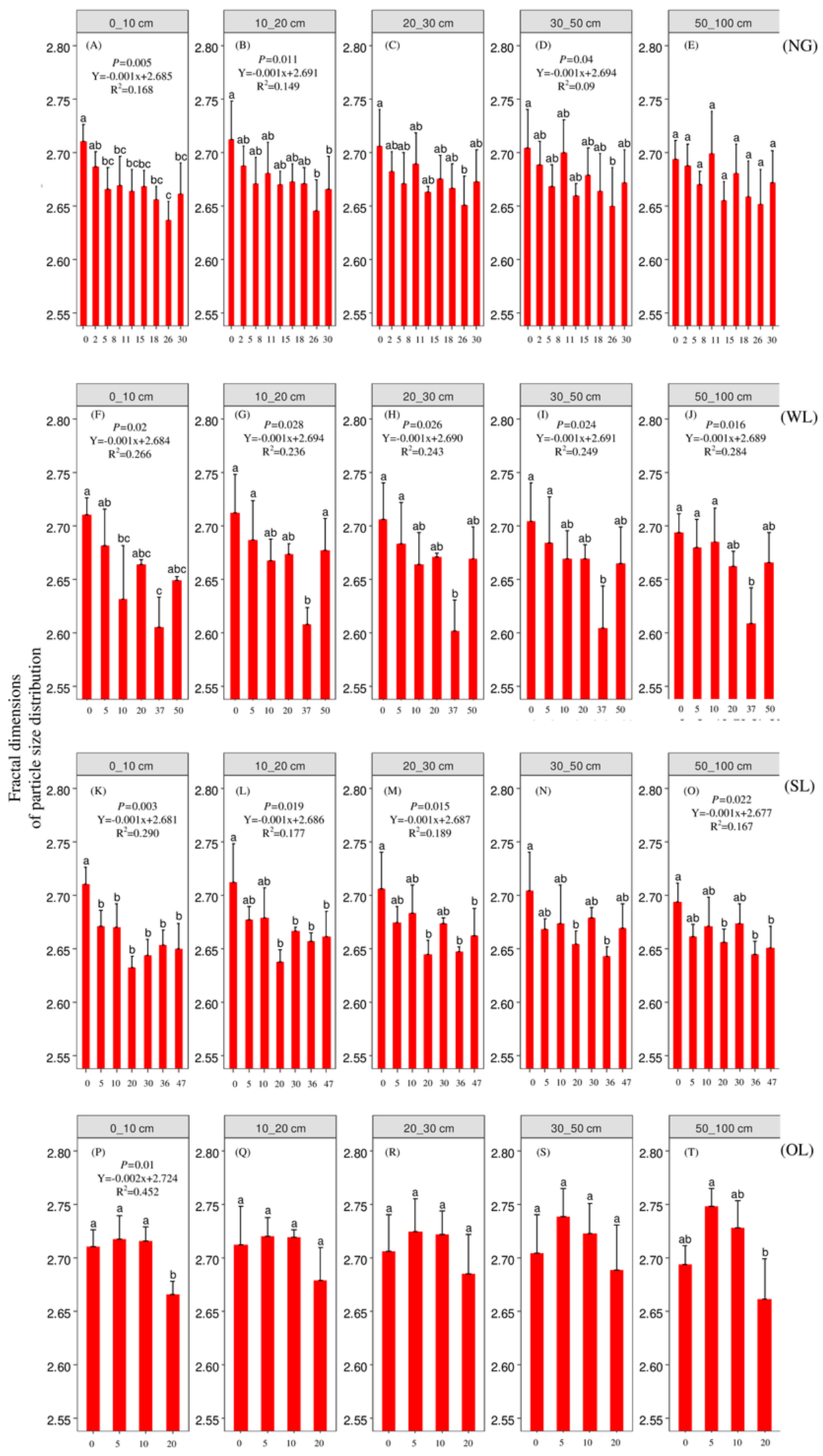


\section{Figure 3}

Fig. 3. Micro-aggregate fractal dimension change with time since cropland abandonment in various vegetation rehabilitation patterns.

Note: NG: naturally revegetated grassland, WL: woodland, SL: shrub land, OL: orchard land. We set the $C L$ as the initial stage of the rehabilitation process. (A-E): the soil layers of $0-10 \mathrm{~cm}, 10-20 \mathrm{~cm}, 20-30 \mathrm{~cm}, 30-50 \mathrm{~cm}$ and $50-100 \mathrm{~cm}$ of naturally revegetated grassland, $(F-$ $\mathrm{K})$ : the soil layers of $0-10 \mathrm{~cm}, 10-20 \mathrm{~cm}, 20-30 \mathrm{~cm}, 30-50 \mathrm{~cm}$ and $50-100 \mathrm{~cm}$ of woodland, (L-O): the soil layers of $0-10 \mathrm{~cm}, 10-20 \mathrm{~cm}, 20-30 \mathrm{~cm}, 30-50 \mathrm{~cm}$ and $50-100 \mathrm{~cm}$ of shrub land, (P-T): the soil layers of $0-10 \mathrm{~cm}, 10-20 \mathrm{~cm}, 20-30 \mathrm{~cm}, 30-50 \mathrm{~cm}$ and $50-100 \mathrm{~cm}$ of orchard land.

Different lower-case letters above the bars mean significant differences among different ages within the same rehabilitation patterns $(P<0.05)$. 

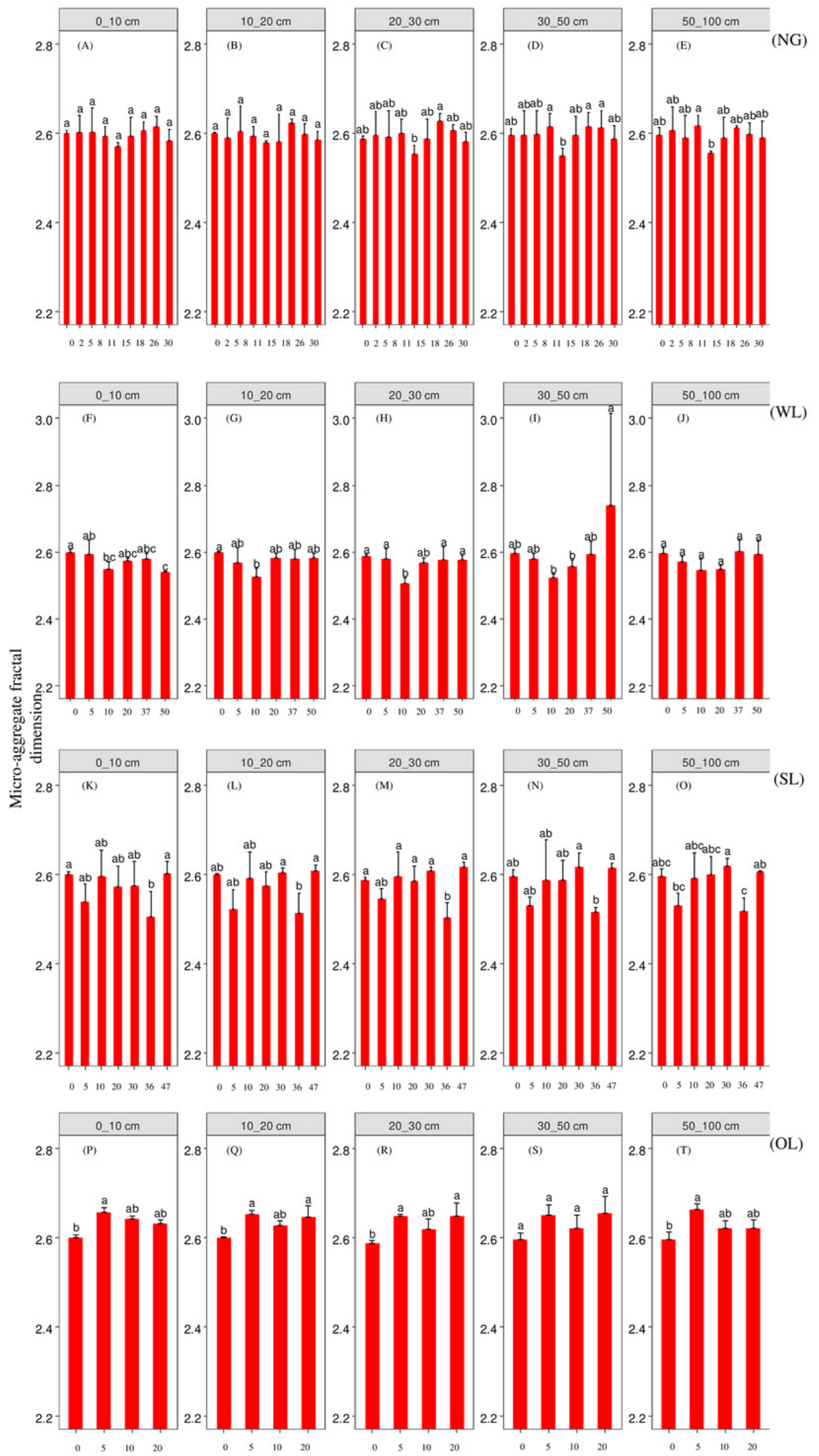


\section{Figure 4}

Fig. 4. Erodibility change with time since cropland abandonment in various vegetation rehabilitation patterns.

Note: NG: naturally revegetated grassland, WL: woodland, SL: shrub land, OL: orchard land. We set the $C L$ as the initial stage of the rehabilitation process. (A-E): the soil layers of $0-10 \mathrm{~cm}, 10-20 \mathrm{~cm}, 20-30 \mathrm{~cm}, 30-50 \mathrm{~cm}$ and $50-100 \mathrm{~cm}$ of naturally revegetated grassland, $(F-$ $\mathrm{K})$ : the soil layers of $0-10 \mathrm{~cm}, 10-20 \mathrm{~cm}, 20-30 \mathrm{~cm}, 30-50 \mathrm{~cm}$ and $50-100 \mathrm{~cm}$ of woodland, (L-O): the soil layers of $0-10 \mathrm{~cm}, 10-20 \mathrm{~cm}, 20-30 \mathrm{~cm}, 30-50 \mathrm{~cm}$ and $50-100 \mathrm{~cm}$ of shrub land, (P-T): the soil layers of $0-10 \mathrm{~cm}, 10-20 \mathrm{~cm}, 20-30 \mathrm{~cm}, 30-50 \mathrm{~cm}$ and $50-100 \mathrm{~cm}$ of orchard land.

Different lower-case letters above the bars mean significant differences among different ages within the same rehabilitation patterns $(P<0.05)$. 


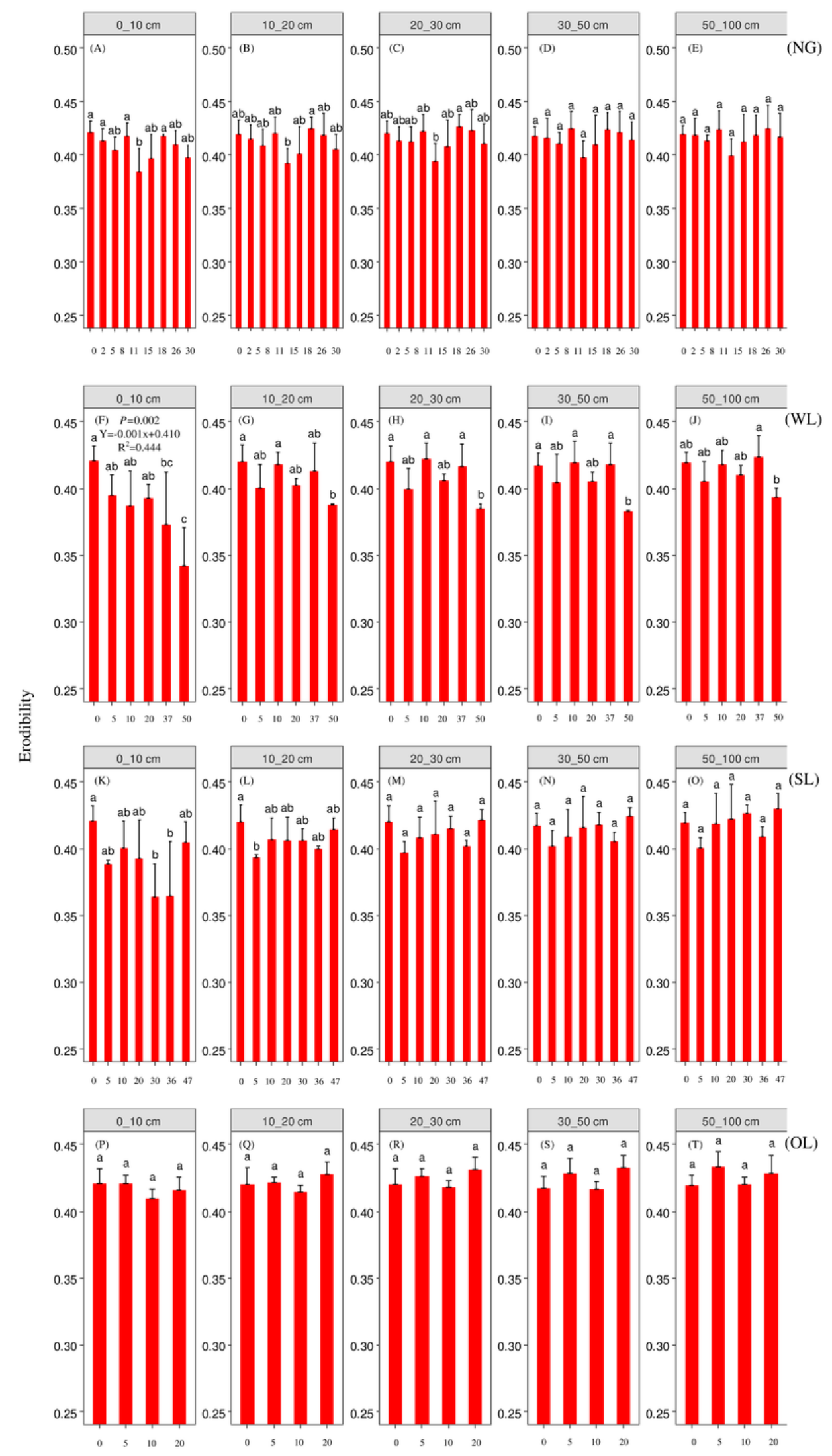




\section{Figure 5}

The differences of particle fractal dimension between the natural forest and various vegetation restoration patterns at each last restoration year.

Note: NG: naturally revegetated grassland, WL: woodland, SL: shrub land, OL: orchard land, NF: natural forest. (A-E): the soil layers of $0-10 \mathrm{~cm}, 10-20 \mathrm{~cm}, 20-30 \mathrm{~cm}, 30-50 \mathrm{~cm}$ and $50-100 \mathrm{~cm}$ of naturally revegetated grassland,(F-K): the soil layers of $0-10 \mathrm{~cm}, 10-20 \mathrm{~cm}$, $20-30 \mathrm{~cm}, 30-50 \mathrm{~cm}$ and $50-100 \mathrm{~cm}$ of woodland, (L-O): the soil layers of $0-10 \mathrm{~cm}, 10-20 \mathrm{~cm}$, $20-30 \mathrm{~cm}, 30-50 \mathrm{~cm}$ and $50-100 \mathrm{~cm}$ of shrub land, (P-T): the soil layers of $0-10 \mathrm{~cm}, 10-20 \mathrm{~cm}$, $20-30 \mathrm{~cm}, 30-50 \mathrm{~cm}$ and $50-100 \mathrm{~cm}$ of orchard land. * means significant differences between the natural forest and various vegetation restoration patterns at each last restoration year ( $P$ $<0.05)$. 

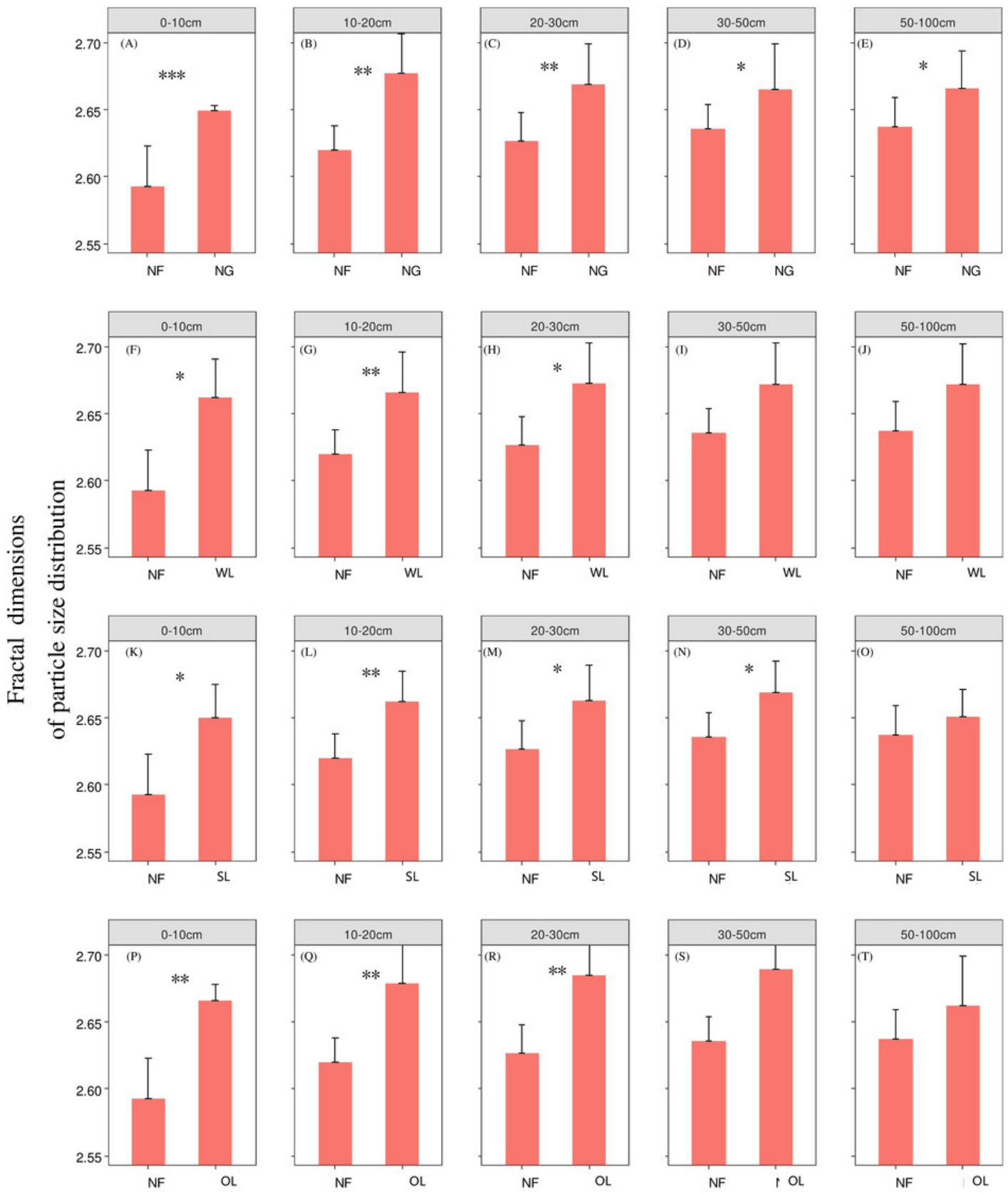


\section{Figure 6}

The differences of micro-aggregate fractal dimension between the natural forest and various vegetation restoration patterns at each last restoration year.

Note: Note: NG: naturally revegetated grassland, WL: woodland, SL: shrub land, OL: orchard land, NF: natural forest. (A-E): the soil layers of $0-10 \mathrm{~cm}, 10-20 \mathrm{~cm}, 20-30 \mathrm{~cm}, 30-50 \mathrm{~cm}$ and $50-100 \mathrm{~cm}$ of naturally revegetated grassland,(F-K): the soil layers of $0-10 \mathrm{~cm}, 10-20 \mathrm{~cm}$, $20-30 \mathrm{~cm}, 30-50 \mathrm{~cm}$ and $50-100 \mathrm{~cm}$ of woodland, (L-O): the soil layers of $0-10 \mathrm{~cm}, 10-20 \mathrm{~cm}$, $20-30 \mathrm{~cm}, 30-50 \mathrm{~cm}$ and $50-100 \mathrm{~cm}$ of shrub land, (P-T): the soil layers of $0-10 \mathrm{~cm}, 10-20 \mathrm{~cm}$, $20-30 \mathrm{~cm}, 30-50 \mathrm{~cm}$ and $50-100 \mathrm{~cm}$ of orchard land. * means significant differences between the natural forest and various vegetation restoration patterns at each last restoration year ( $P$ $<0.05)$. 

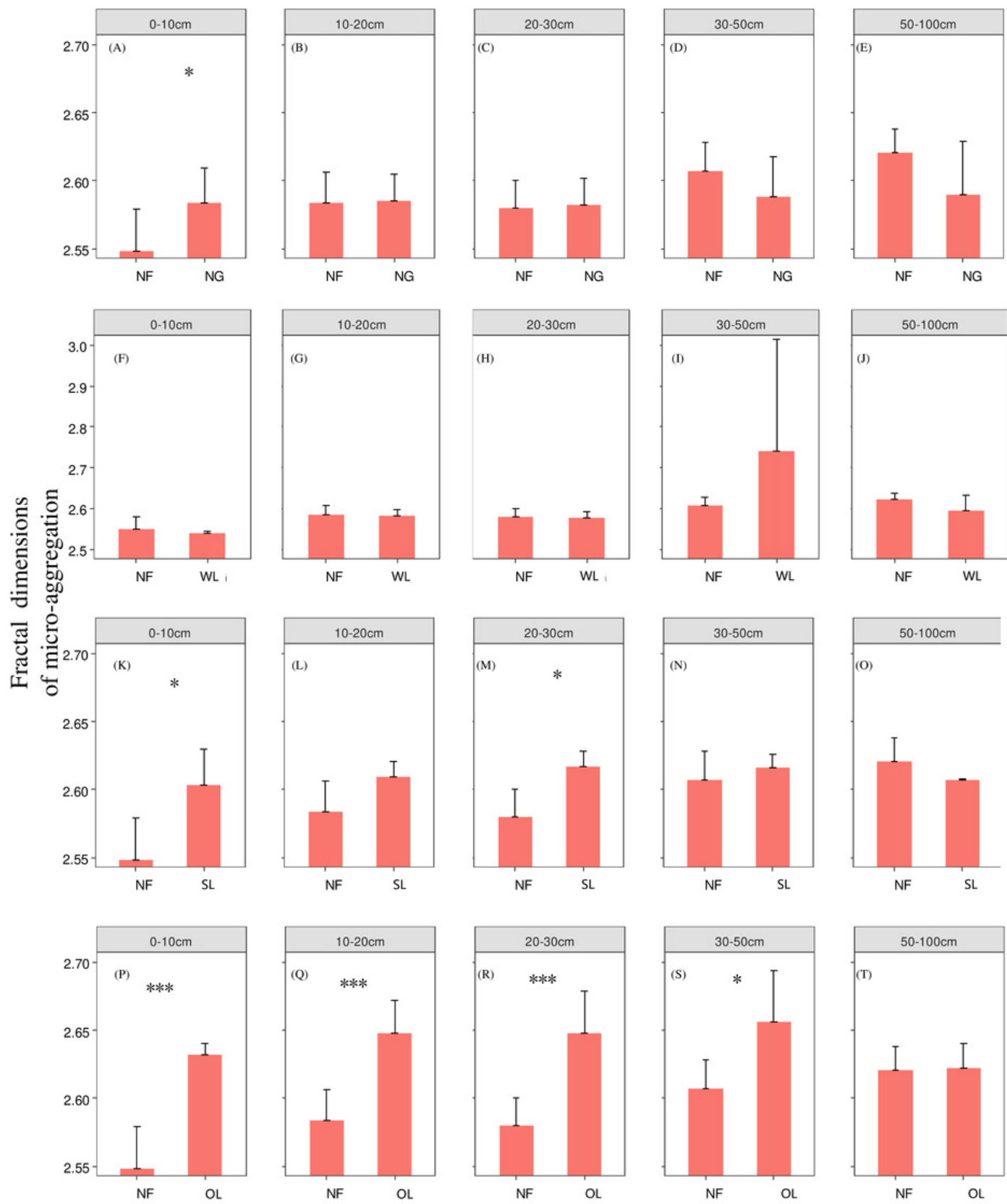


\section{Figure 7}

The differences of erodibility between the natural forest and various vegetation restoration patterns at each last restoration year.

Note: NG: naturally revegetated grassland, WL: woodland, SL: shrub land, OL: orchard land, NF: natural forest. (A-E): the soil layers of $0-10 \mathrm{~cm}, 10-20 \mathrm{~cm}, 20-30 \mathrm{~cm}, 30-50 \mathrm{~cm}$ and $50-100 \mathrm{~cm}$ of naturally revegetated grassland,(F-K): the soil layers of $0-10 \mathrm{~cm}, 10-20 \mathrm{~cm}$, $20-30 \mathrm{~cm}, 30-50 \mathrm{~cm}$ and $50-100 \mathrm{~cm}$ of woodland, (L-O): the soil layers of $0-10 \mathrm{~cm}, 10-20 \mathrm{~cm}$, $20-30 \mathrm{~cm}, 30-50 \mathrm{~cm}$ and $50-100 \mathrm{~cm}$ of shrub land, (P-T): the soil layers of $0-10 \mathrm{~cm}, 10-20 \mathrm{~cm}$, $20-30 \mathrm{~cm}, 30-50 \mathrm{~cm}$ and $50-100 \mathrm{~cm}$ of orchard land. * means significant differences between the natural forest and various vegetation restoration patterns at each last restoration year ( $P$ $<0.05)$. 

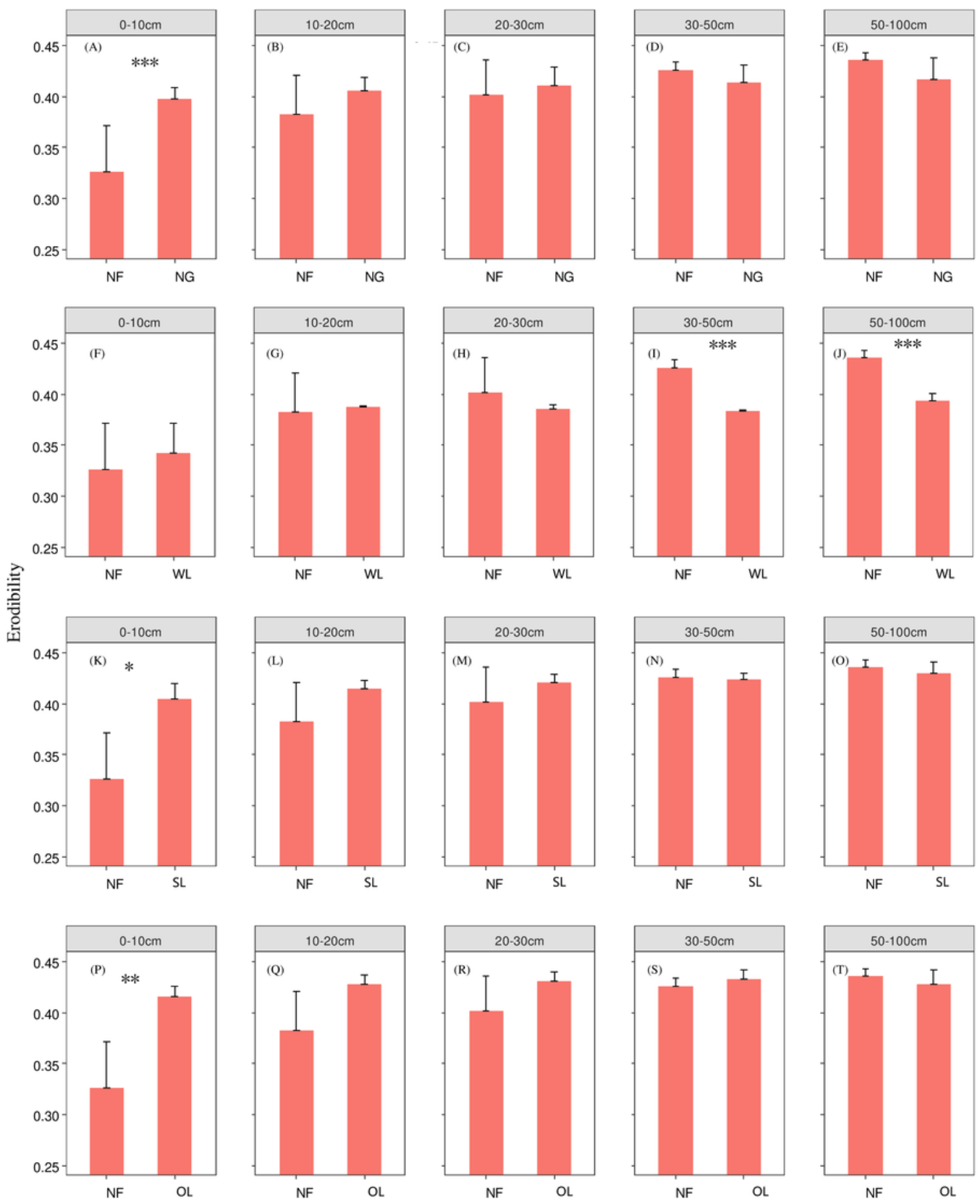


\section{Figure 8}

Biplot of the first two RDA axes between the vegetation Rehabilitation patterns, soil depth, restoration time and fractal dimension, erodibility( $K$ factor), TC, TOC, TN, each classes particles and micro-aggregate.

Biplot of the first two RDA axes between the vegetation Rehabilitation patterns, soil depth, restoration time and fractal dimension, erodibility ( K factor), TC, TOC, TN, each classes particles and micro-aggregate. 


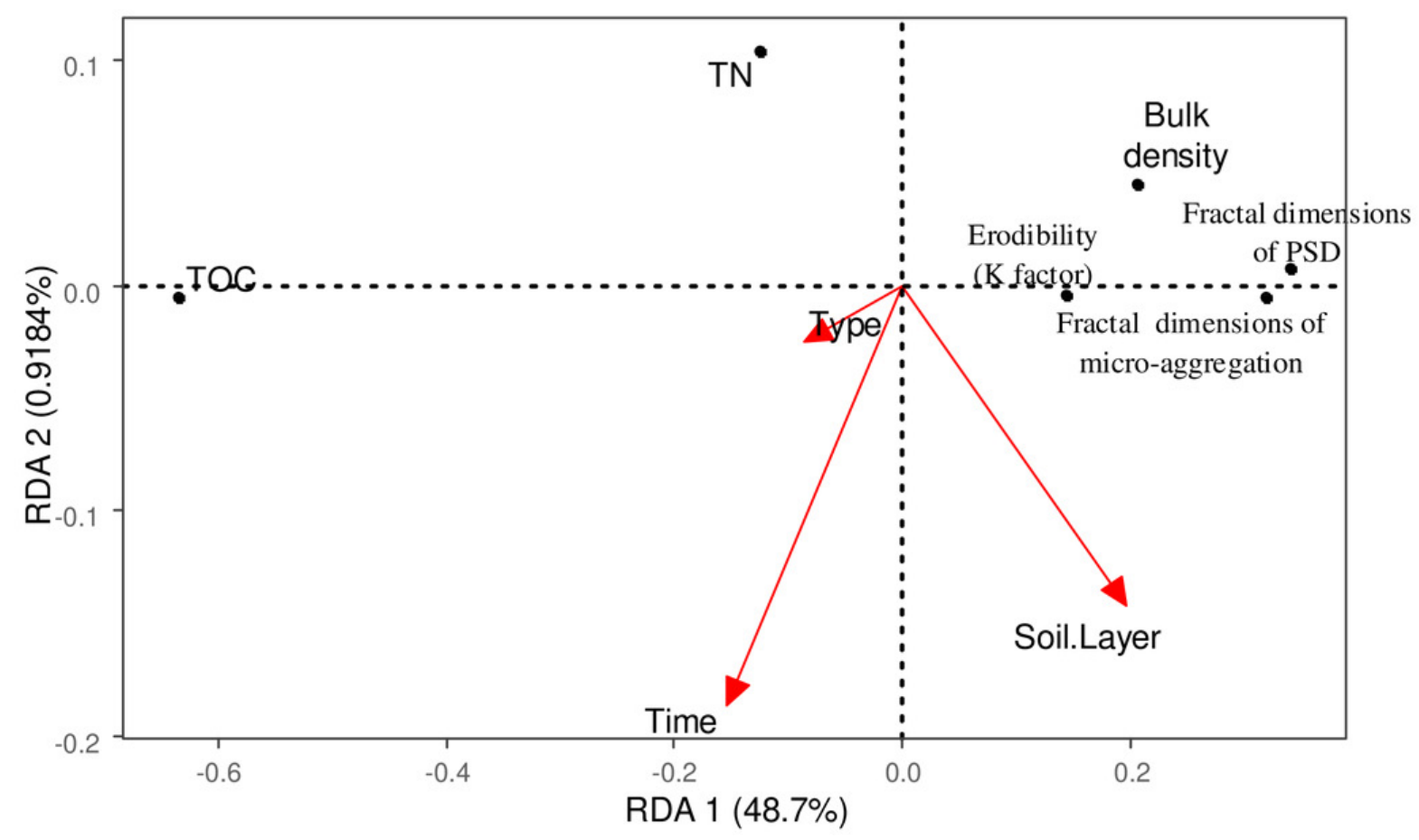




\section{Table 1 (on next page)}

Table 1 Basic information of sample plots

Table 1 Basic information of sample plots 


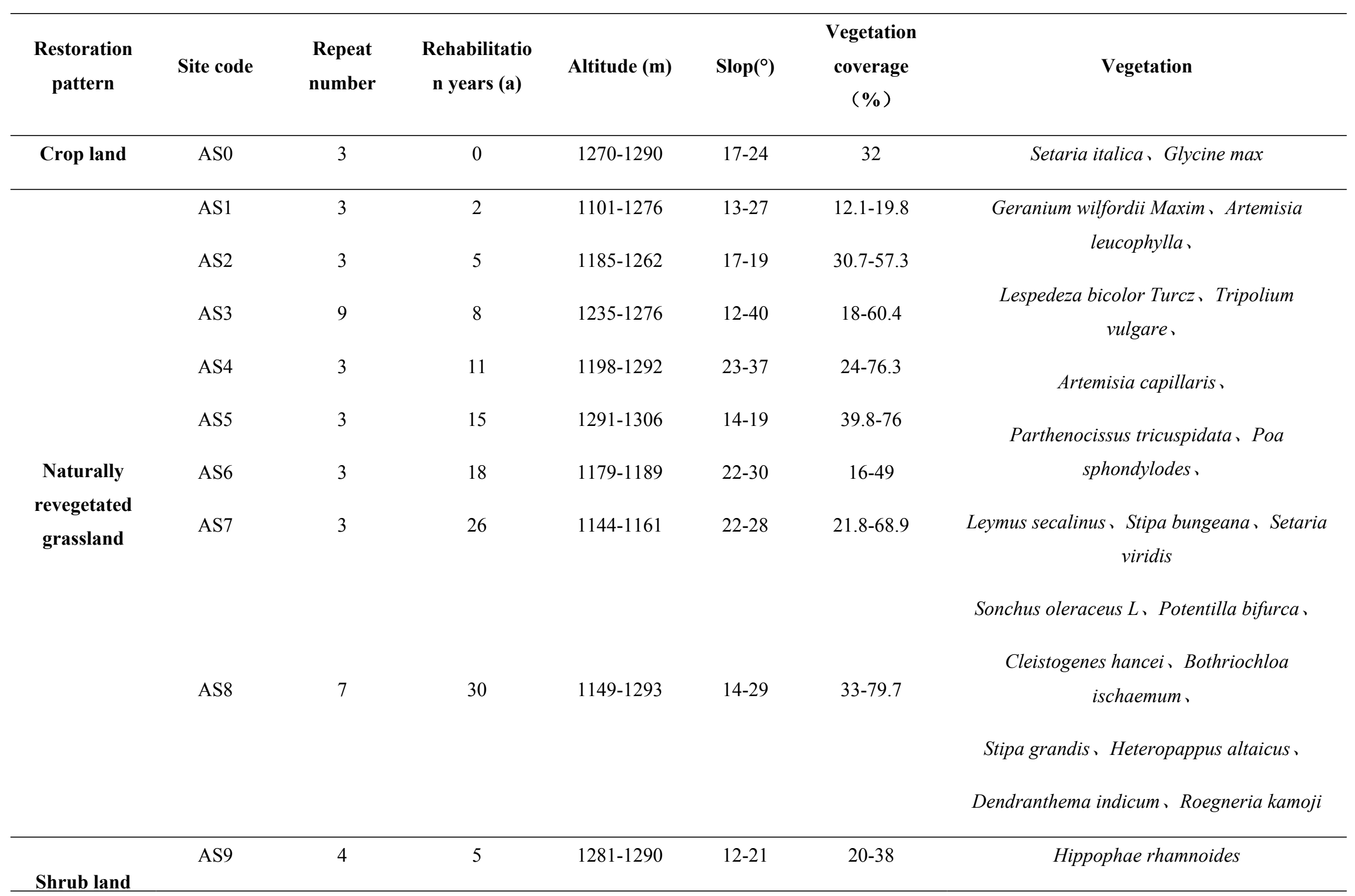




\begin{tabular}{|c|c|c|c|c|c|c|c|}
\hline & AS10 & 3 & 10 & $1139-1161$ & $29-32$ & $53-78.4$ & Caragana korshinskii Kom. \\
\hline & AS11 & 3 & 10 & $1264-1281$ & $14-27$ & $36-57$ & \\
\hline & AS12 & 4 & 20 & 1185 & 21 & 52 & \\
\hline & AS13 & 3 & 20 & $1203-1211$ & $21-22$ & $28-53$ & \\
\hline & AS14 & 3 & 30 & $1128-1139$ & $14-25$ & $21-46.3$ & \\
\hline & AS15 & 3 & 36 & $1211-1253$ & 20 & $46-65$ & \\
\hline & AS16 & 3 & 47 & $1181-1241$ & $18-24$ & $49.3-89.6$ & \\
\hline \multirow{6}{*}{ Wood land } & AS17 & 3 & 5 & $1259-1288$ & $22-34$ & $36-56$ & \multirow{5}{*}{ Robinia pseudoacacia Linn. } \\
\hline & AS18 & 3 & 10 & $1161-1227$ & $27.5-33$ & $38-53$ & \\
\hline & AS19 & 3 & 20 & $1236-1259$ & $17-26$ & $32-42$ & \\
\hline & AS20 & 3 & 37 & $1209-1259$ & $30-33$ & $53-65$ & \\
\hline & AS21 & 2 & 56 & $1170-1175$ & $21-22$ & $49-90$ & \\
\hline & AS22 & 3 & 5 & $1207-1226$ & 0 & & \multirow{3}{*}{ Malus pumila Mill. } \\
\hline \multirow[t]{2}{*}{ Orchard land } & AS23 & 3 & 10 & $1220-1254$ & 0 & & \\
\hline & AS24 & 3 & 20 & $1206-1222$ & 0 & & \\
\hline $\begin{array}{c}\text { Natural forest } \\
\text { land }\end{array}$ & AS25 & 9 & 100 & $1332-1337$ & $14-29$ & $39-52$ & Quercus wutaishanica Blume. \\
\hline
\end{tabular}




\begin{tabular}{lcccc}
\hline AS26 & 100 & $1235-1283$ & $23-38$ & $35-70$ \\
AS27 & 100 & $1552-1570$ & $28-45$ & $10-28$ \\
\hline
\end{tabular}




\section{Table 2 (on next page)}

Table 2 Tests of the soil particle fractal dimension, micro-aggregate fractal dimension, erodibility linkage with time(years since cropland abandonment), Rehabilitation pattern and soil depth

${ }^{* *}$ Indicates a significant difference at the 0.01 level $(P<0.01){ }^{* * *}$ Indicates a significant difference at the 0.001 level $(P<0.001)$. 


\begin{tabular}{|c|c|c|c|c|c|c|}
\hline \multirow[t]{2}{*}{ Source } & \multicolumn{2}{|c|}{ Particles fractal dimension $(\mathrm{PD})$} & \multicolumn{2}{|c|}{$\begin{array}{l}\text { Micro-aggregate fractal dimension } \\
\text { (MD) }\end{array}$} & \multicolumn{2}{|c|}{ Erodibility $(\mathrm{K})$} \\
\hline & $\mathrm{F}$ & $P$ & $\mathrm{~F}$ & $P$ & $\mathrm{~F}$ & $P$ \\
\hline Rehabilitation types & 34.111 & $0.000 * * *$ & 4.901 & $0.002^{* *}$ & 10.007 & $0.000^{* *}$ \\
\hline Rehabilitation time & 15.283 & $0.000 * * *$ & 0.943 & 0.508 & 5.491 & $0.000^{* *}$ \\
\hline Soil depth & 3.282 & $0.012 *$ & 0.108 & 0.98 & 25.056 & $0.000^{* *}$ \\
\hline Rehabilitation time $\times$ Rehabilitation types & 4.16 & $0.001 * * *$ & 0.628 & 0.678 & 2.127 & 0.06 \\
\hline Soil depth $\times$ Rehabilitation types & 0.143 & 1 & 0.568 & 0.867 & 0.393 & 0.96 \\
\hline Soil depth $\times$ Rehabilitation time & 0.278 & 1 & 0.321 & 1 & 0.379 & \\
\hline Rehabilitation time $\times$ Soil depth $\times$ Rehabilitation types & 0.568 & 0.933 & 0.824 & 0.685 & 0.349 & 0.99 \\
\hline
\end{tabular}




\section{Table 3 (on next page)}

Table 3 Relationships between particle fractal dimension, micro-aggregate fractal dimension, erodibility and soil nutrients and soil bulk density.

*Correlation is significant at the $P \square 0.05$ level (2-tailed); ${ }^{*}$ Correlation is significant at the $P$ 00.01 level (2-tailed) *** 


\begin{tabular}{cccc}
\hline & BD & TOC & TN \\
\hline particle fractal dimension fractal dimension & $0.185^{* *}$ & $-0.380^{* *}$ & \\
micro-aggregate fractal dimension fractal & & $-0.146^{* *}$ \\
dimension & 0.018 & -024 & 0.048 \\
erodibility & & $-0.658 *$ & $-0.399 *$
\end{tabular}

